\title{
Biological and therapeutic effects of ortho-silicic acid and some ortho-silicic acid-releasing compounds: New perspectives for therapy
}

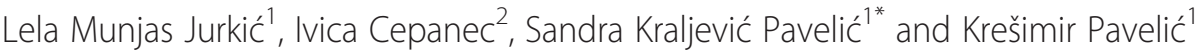

\begin{abstract}
Silicon (Si) is the most abundant element present in the Earth's crust besides oxygen. However, the exact biological roles of silicon remain unknown. Moreover, the ortho-silicic acid $\left(\mathrm{H}_{4} \mathrm{SiO}_{4}\right)$, as a major form of bioavailable silicon for both humans and animals, has not been given adequate attention so far. Silicon has already been associated with bone mineralization, collagen synthesis, skin, hair and nails health atherosclerosis, Alzheimer disease, immune system enhancement, and with some other disorders or pharmacological effects. Beside the ortho-silicic acid and its stabilized formulations such as choline chloride-stabilized ortho-silicic acid and sodium or potassium silicates (e.g. $\mathrm{M}_{2} \mathrm{SiO}_{3} ; \mathrm{M}=\mathrm{Na}, \mathrm{K}$ ), the most important sources that release ortho-silicic acid as a bioavailable form of silicon are: colloidal silicic acid (hydrated silica gel), silica gel (amorphous silicon dioxide), and zeolites. Although all these compounds are characterized by substantial water insolubility, they release small, but significant, equilibrium concentration of ortho-silicic acid $\left(\mathrm{H}_{4} \mathrm{SiO}_{4}\right)$ in contact with water and physiological fluids. Even though certain pharmacological effects of these compounds might be attributed to specific structural characteristics that result in profound adsorption and absorption properties, they all exhibit similar pharmacological profiles readily comparable to ortho-silicic acid effects. The most unusual ortho-silicic acid-releasing agents are certain types of zeolites, a class of aluminosilicates with well described ion(cation)-exchange properties. Numerous biological activities of some types of zeolites documented so far might probably be attributable to the ortho-silicic acid-releasing property. In this review, we therefore discuss biological and potential therapeutic effects of ortho-silicic acid and ortho-silicic acid -releasing silicon compounds as its major natural sources.
\end{abstract}

Keywords: Silicon, Orthosilicic acid, Zeolites, Therapeutic and biological effects

\section{Introduction}

Silicon ( $\mathrm{Si}$ ) is the most abundant element (27.2\%) present in the earth's crust following oxygen (45.5\%) [1]. Silicon is known for a number of important chemical and physical properties, i.e. semiconductor property that are used in various scientific and technical applications. These Si features, along with structural complexity of its compounds, have attracted researchers from the earliest times [2]. In particular, silicon dioxide or silica $\left(\mathrm{SiO}_{2}\right)$ is the most studied chemical compound following water, and the most important $\mathrm{Si}$-containing inorganic substance [1]. Formally, silica $\left(\mathrm{SiO}_{2}\right)$ is a silicic acid

\footnotetext{
* Correspondence: sandrakp@biotech.uniri.hr

'Department of Biotechnology, University of Rijeka, Radmile Matejčić 2, Rijeka HR-51000, Croatia

Full list of author information is available at the end of the article
}

anhydride of monomeric ortho-silicic acid $\left(\mathrm{H}_{4} \mathrm{SiO}_{4}\right)$, which is water soluble and stable in highly diluted aqueous solutions. Moreover, several "lower" hydrated forms of ortho-silicic acid exist in aqueous solutions as well including meta-silicic acid $\left(\mathrm{H}_{2} \mathrm{SiO}_{3}\right.$ or lower oligomers like di-silicic $\left(\mathrm{H}_{2} \mathrm{Si}_{2} \mathrm{O}_{5}\right)$ and tri-silicic acids $\left(\mathrm{H}_{2} \mathrm{Si}_{3} \mathrm{O}_{7}\right)$ including their hydrated forms pentahydro-silicic $\left(\mathrm{H}_{10} \mathrm{Si}_{2} \mathrm{O}_{9}\right)$, and pyro-silicic acids $\left(\mathrm{H}_{6} \mathrm{Si}_{2} \mathrm{O}_{7}\right)$ [1]. These are water soluble, formed in reversible equilibrium reactions from $\mathrm{H}_{4} \mathrm{SiO}_{4}$ and stable in diluted aqueous solutions. During a prolonged storage period, at increased concentration or in an acidic environment, these low molecular silicic acids undergo further condensation by cross-linking and dehydration. This process results in formation of polysilicic acids chains of variable composition $\left[\mathrm{SiO}_{\mathrm{x}}(\mathrm{OH})_{4-2 \mathrm{x}}\right]$ and complex structure [1]. The end product is a jelly-like

\section{Ciomed Central}


precipitate, namely hydrated silica $\left(\mathrm{SiO}_{2} \bullet \mathrm{xH}_{2} \mathrm{O}\right.$; often referred as "colloidal silicic acid" or "hydrated silica gel"). Further condensation follows which is accompanied by dehydration yielding less hydrated silicon dioxide $\left(\mathrm{SiO}_{2}\right)$ phases, also known as "silica gel" or "amorphous silicon dioxide".

Lower molecular forms, especially the ortho-silicic acid $\left(\mathrm{H}_{4} \mathrm{SiO}_{4}\right.$; Figure 1), play a crucial role in delivering silicon to the living organisms' cells and thus represent major sources of silicon for both humans and animals. Most of the silica in aqueous systems and oceans is available in the form of $\mathrm{H}_{4} \mathrm{SiO}_{4}$, which makes it an important compound in environmental silicon-chemistry and biology [3]. In this paper, we critically review the most recent findings on biological effects of $\mathrm{Si}$ and ortho-silicic acid on animals and human beings. Moreover, we propose that previously observed positive biological effects of various colloidal silicic acids (various hydrated silica gels) as well as some zeolites [4-6], e.g. zeolite A (Figure 2) and clinoptilolite (Figure 3), might be, at least partially, ascribed to the ortho-silicic acid-releasing property.

Silicon represents the third most abundant trace element in the human body $[7,8]$. For example, it is present in 1-10 parts-per-million (ppm) in hair [9], nails [10], in the cornfield epidermis, and in the epicuticle of hair $[11,12]$. Silicon is naturally present in food as a silicon dioxide $\left(\mathrm{SiO}_{2}\right)$, free ortho-silicic acid $\left(\mathrm{H}_{4} \mathrm{SiO}_{4}\right)$, silicic acids bounded to certain nutrients, and in the silicate form. Although silicon is a life-important micronutrient mineral, in our opinion it has not received adequate attention. Considering the abundance of silicon, both in the nature and humans, it is expected that it should play an important role in human and animal health.

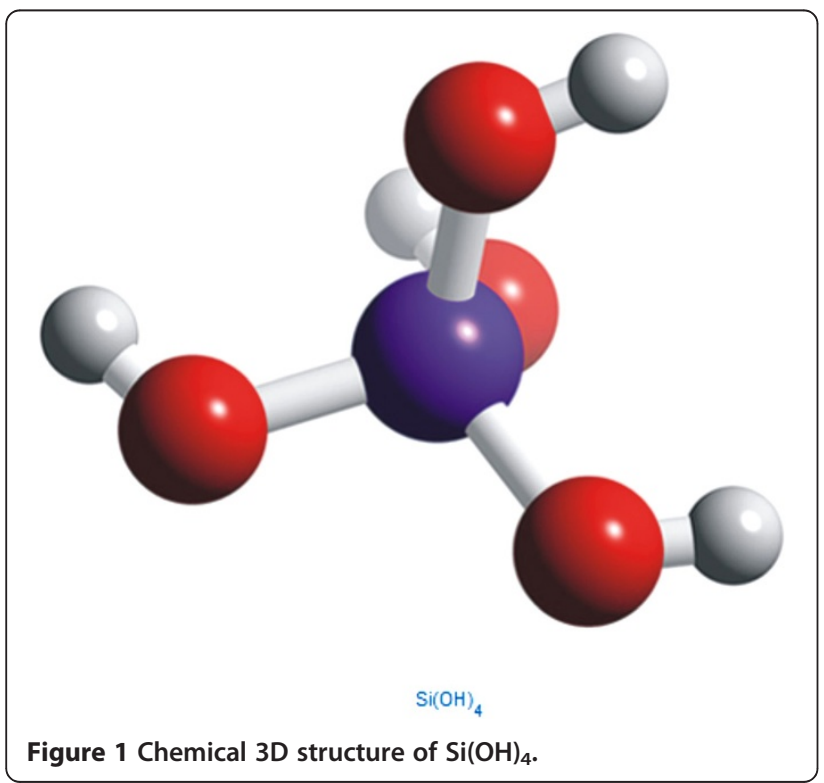

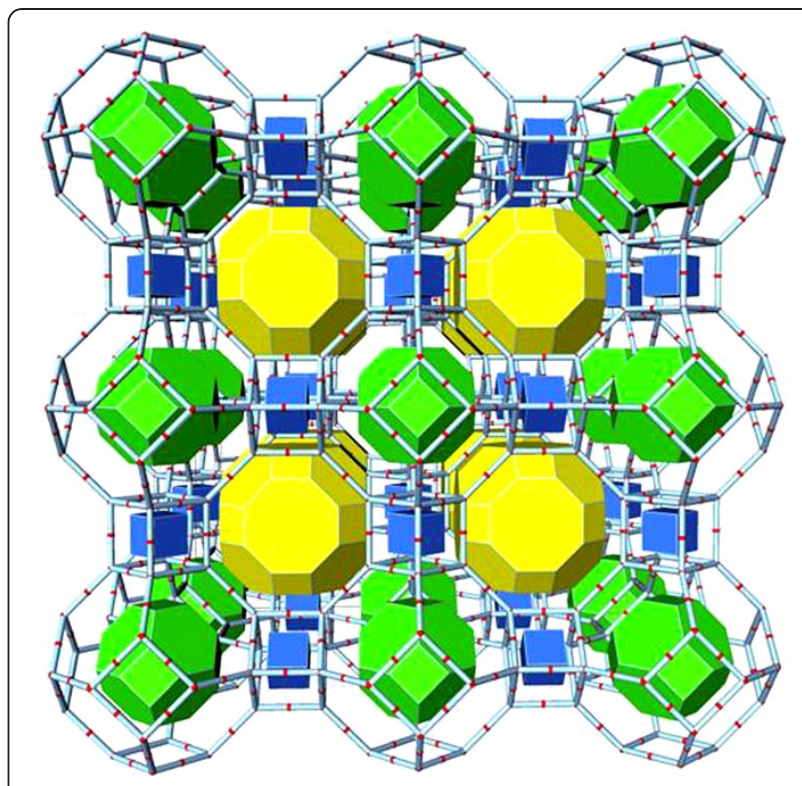

Figure 2 Zeolite A structure: an assembly of framework's cages (tiles). Centre of a tile is the centre of a void in the framework. Voids are connected with adjacent ones through the large "windows" which are faces of tiles.

\section{Silicon bioavailability and consumption}

Presently, many biological roles of silicon remain unknown [13]. Consequently, the recommended daily silicon intake (RDI) has not yet been set $[13,14]$. Considering the risk assessment of amorphous silicon dioxide as common silicon source (e.g. food additive E551), the safe upper intake level (UIL) may be estimated as $700 \mathrm{mg} /$ day for adults, that is the equivalent to $12 \mathrm{mg}$ silicon $/ \mathrm{kg}$ bw/day for a $60 \mathrm{~kg}$ adult [15]. These numbers refer to the

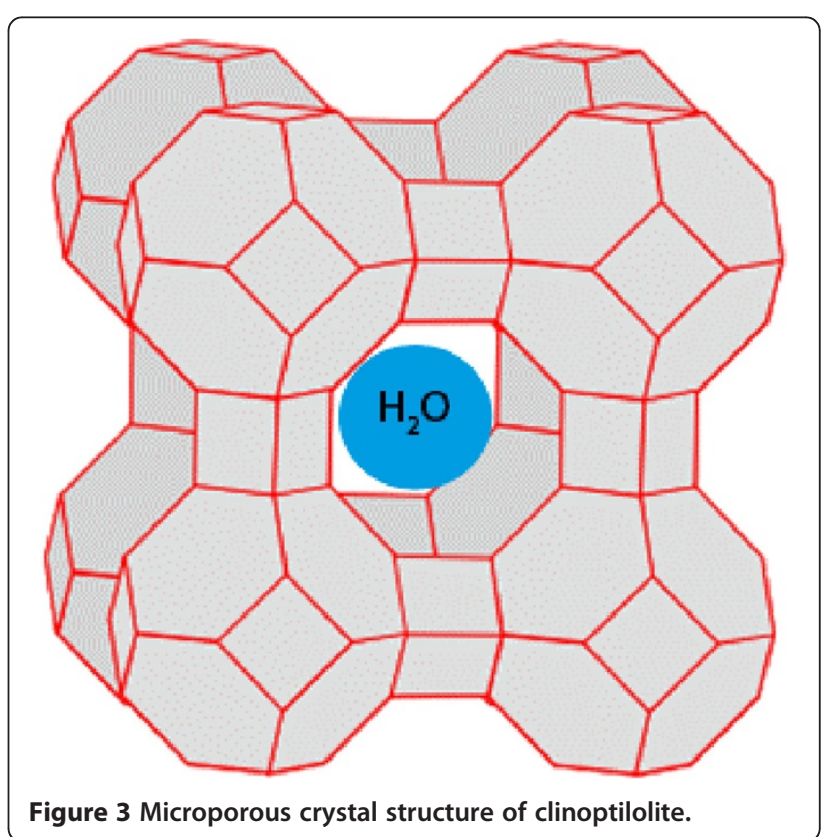


amorphous silicon dioxide form and only small amounts of silicon ( $\left.\mathrm{as}_{4} \mathrm{SiO}_{4}\right)$ are actually released in the gastrointestinal (GI) tract and subsequently absorbed in the systemic circulation. Due to lack of data, it is difficult to set a recommended upper intake level for silicon. Moreover, little information on the intake of dietary silicon by humans is available. A mean intake of daily silicon has been reported in Finland [16], (29 mg silicon/day) and in a typical British diet (20-50 mg silicon/day) [17-19]. This corresponds to $0.3-0.8 \mathrm{mg} / \mathrm{silicon} / \mathrm{kg}$ bw/day for a $60 \mathrm{~kg}$ person. These data are in the same range as the estimated mean intakes of silicon in the USA ( 30 and $33 \mathrm{mg}$ silicon/ day in men, and 24 and $25 \mathrm{mg}$ silicon/day in women, respectively) [8]. Silicon intake decreases with age to less than $20 \mathrm{mg}$ silicon/day $(18.6 \pm 4.6 \mathrm{mg}$ silicon/day for elderly British woman in an unrelated randomised controlled intervention study) [20].

Generally, silicon is abundantly present in foods derived from plants such as: cereals, oats, barley, white wheat flour, and polished rice. In contrast, silicon levels are lower in animal foods including meat or dairy products. Furthermore, silicon is present in drinking waters, mineral waters, and in beer as well [17]. However, Jugdaohsingh et al. [21] raised some doubt on utilisation of silicon from drinking water in an animal rat study as no significant differences were found in the silicon bone concentration when the drinking water was supplemented with silicon in the ortho-silicic acid form. Indeed, the major sources of silicon in the typical Western hemisphere diet comes from cereals (30\%), followed by fruits, beverages and vegetables, which altogether comprise around $75 \%$ of total silicon intake [20]. Even though plant food contains high levels of silicon, its bioavailability from these sources is questionable, due to poor solubility of actual silicon forms present in these foods $[18,19,22]$. Efficient absorption in the GI tract would require their breakdown to soluble species such as orthosilicic acid, present in drinking and mineral waters in the range of 2 to $5 \mathrm{mg}$ silicon/L [23] and in beer ranging from 9 to $39 \mathrm{mg}$ silicon/L $[18,24]$. Absorption studies indicate that the ortho-silicic acid is a main readily bioavailable source of silicon for humans, whereas its higher polymers are not of significant absorbability [25]. In a placebo-controlled study on eight volunteers, Jugdaohsingh et al. [25] showed that 53\% of administered ortho-silicic acid is excreted in the urine, whereas the ingestion of polymeric silicic acid causes only a marginal increase of silicon in the urine. This result substantiates the statement that polymeric silicic acids and amorphous silicon dioxide are of poor bioavailability.

Besides the ortho-silicic acid, water soluble silicates are bioavailable silicon forms as well. For instance, pharmaceutically acceptable alkali metals silicates $\left(\mathrm{M}_{2} \mathrm{SiO}_{3} ; \mathrm{M}=\right.$ $\mathrm{Na}, \mathrm{K}$ ) in adequately diluted aqueous solutions, release ortho-silicic acid $\left(\mathrm{H}_{4} \mathrm{SiO}_{4}\right)$ upon contact with stomach hydrochloric acid ( $\mathrm{HCl})$. Popplewell et al. [26] employed a tracer dose of radiolabelled ammonium silicate to measure total uptake and urine excretion. Their results revealed that $36 \%$ of ingested dose was absorbed and completely excreted in urine within $48 \mathrm{~h}$. However, elimination occurred in two steps where the major dose $(90 \%)$ has been excreted within the first 2.7 hours. They suggested that excess silicon is eliminated from the body through two distinct processes, differing significantly in the duration. The 'slower process' is thought to include the intracellular uptake and release of silicon, whilst the 'faster process' probably includes retention of silicon in the extracellular fluids [26]. These data report on increased silicon levels in serum upon consumption of silicon-rich food [7,27], showing that at least some silicon is available from food as well. Indeed, selective silicon deprivation in rats showed a significant drop of urinary silicon excretion and fasting silicon serum concentration, suggesting that the rats actively regulate silicon levels via urinary conservation, perhaps through renal re-absorption [21]. Most of silicon present in the serum is filtered by the kidney $[7,28]$ suggesting the kidney as its major excretion route; silicon levels in serum correlate with those in urine. However, it is still not clear how and if the body can efficiently retain adequate doses of silicon.

In concentrated solutions, ortho-silicic acid $\left(\mathrm{H}_{4} \mathrm{SiO}_{4}\right)$ has to be stabilized to avoid its polymerization into polysilicic acids and eventually into silica gel, resulting in a decreased silicon bioavailability. This issue has been solved in the field of pharmaceutical technology by use of choline chloride in aqueous glycerol solution. This resulted in development of a liquid formulation known as choline-stabilized ortho-silicic acid (ch-OSA). Choline chloride-stabilized ortho-silicic acid is not a new chemical entity of ortho-silicic acid, but a complex of $\mathrm{H}_{4} \mathrm{SiO}_{4}$ and choline chloride formed by several possible hydrogen bonds between these two compounds. Subsequently, from the standpoint of nutrition and pharmacology, the effects of ch-OSA must involve effects of both $\mathrm{H}_{4} \mathrm{SiO}_{4}$ and choline chloride rather than a new chemical entity. Due to a possible impact of choline chloride on the chemical stability of $\mathrm{H}_{4} \mathrm{SiO}_{4}$, certain specific biological effects different from those of a pure ortho-silicic acid or its immediate releasing compounds (e.g. sodium silicate), must be taken in account. Ch-OSA has been approved for human consumption and is known to be non-toxic. Its lethal doses (LD) exceed $5000 \mathrm{mg} / \mathrm{kg}$ bw in humans [29] and $6640 \mathrm{mg} / \mathrm{kg}$ bw in animals [30]. The ch-OSA represents the most bioavailable source of silicon $[22,29]$. Moreover, in a randomized placebo-controlled study [29], the bioavailability of ch-OSA during maternal transfer to the offspring was investigated in a supplementation study with pigs. The authors correlated 
significantly higher silicon concentrations in the serum of weanling piglets from supplemented sows and maternal transfer of absorbed silicon between sows and their offspring during lactation with high bioavailability of silicon from ch-OSA. Importantly, highly bioavailable silicon from ch-OSA did not altered calcium, phosphorus and magnesium levels in blood.

\section{Therapeutic and biological effects of ortho-silicic acid and certain ortho-silicic acid-releasing compounds}

It was reported that silicon is connected with bone mineralization and osteoporosis [31], collagen synthesis and ageing of skin [11], condition of hair and nails [32], atherosclerosis [33,34], Alzheimer disease [9,35,36], as well as with other biological effects and disorders. Trace minerals are known to generally play a vital role in the human body homeostasis [37] and the serum levels of silicon are similar to other trace elements, i.e. of iron, copper, and zinc [38]. Silicon is excreted through the urine in similar orders of magnitude as calcium. Some researches claim that silicon does not act as a proteinbounding element in plasma and is believed to exist almost entirely as un-dissociated monomeric orthosilicic acid [28]. While early analyses showed that serum contains 50-60 $\mu \mathrm{g}$ silicon/dL [38,39], more recent analyses indicate that human serum contains $11-25 \mu \mathrm{g}$ silicon/dL, or levels ranging between 24 and $31 \mu \mathrm{g} / \mathrm{dL}$ ( 8.5 and $11.1 \mu \mathrm{mol} / \mathrm{L}$ ), detected by absorption spectrometry in large population groups [40]. Interestingly, pregnant women had very low serum silicon concentrations (3.3-4.3 $\mu \mathrm{g} / \mathrm{dL})$ in comparison with infants that have high concentrations between 34 and $69 \mu \mathrm{g} / \mathrm{dL}[27,41]$. Moreover, silicon concentrations in serum showed a statistically significant age and sex dependency, as it seems that silicon concentrations decrease with age, especially in woman [40].

Biological importance of silicon might be analysed in the context of its bio-distribution in the body. For example, the highest silicon concentration has been measured in connective tissues, especially in the aorta, tracheas, bone, and skin. Low levels of silicon in the form of ortho-silicic acid [42-44] may be found in liver, heart, muscle, and lung [45]. It is therefore plausible to assume that observed decrease of silicon concentration in the ageing population may be linked to several degenerative disorders, including atherosclerosis. Supplementation of the regular diet with bioavailable forms of silicon may therefore have a therapeutic potential including prevention of degenerative processes. Several experiments have already confirmed this hypothesis. For example, in a controlled animal study, spontaneously hypertensive rats had lower blood pressure upon supplementation with soluble silicon [44], whilst silicon deficiency in animals has been found to be connected with bone defects and impaired synthesis of connective tissue compounds, such as collagen and glycosaminoglycans [46-48]. It is therefore reasonable to assume that silicon deficiency or lower bioavailability may be linked to problems with bone structure and collagen production. Moreover, silicon was shown to be uniquely localized in active growth areas in young bones of animals where a close relationship between silicon concentration and the degree of mineralization has been assessed $[46,49]$. Studies confirmed the essential role of silicon in the growth and skeletal development of chicks that during silicon deprivation showed significantly retarded skeletal development [50]. Experimental silicon deprivation in rats [51-53] and chicks $[46,47]$ demonstrated striking effects on skeletal growth and bone metabolism as well. On the other hand, the controlled animal study of Jugdaohsingh et al. [21] showed no profound effects of a silicon-deficient diet on the bone growth and skeletal development in rats. Silicon concentrations in the tibia and soft tissues did not differ from those in rats on a silicon-deficient diet where the silicon was supplemented in drinking water. Nevertheless, silicon levels in tibia were much lower compared to the reference group fed by a silicon rich diet. Body and bone lengths were also found to be lower in comparison with the reference group, while reduction in bone growth plate thickness was found in silicon deprived rats [21].

Moreover, Reffit et al. [54] found that ortho-silicic acid stimulates collagen type 1 synthesis in human osteoblastlike cells and skin fibroblasts and enhances osteoblastic differentiation in the MG-63 cells in vitro. Ortho-silicic acid did not alter collagen type 1 gene expression, but it modulated the activity of prolyl hydroxylase, an enzyme involved in the production of collagen [55]. Similarly, Schütze et al. [56] reported that the zeolite A stimulated DNA synthesis in osteoblasts and inhibited osteoclastmediated bone resorption in vitro. This is probably attributable to the ortho-silicic acid-releasing property of zeolite A.

The mechanism underlying observed biological effects of silicon may probably be ascribed to its interrelationships with other elements present in the body such as molybdenum [57] aluminium [9,35,58,59], and calcium $[46,49,50]$. For instance, it was proven that silicon levels are strongly affected by molybdenum intake, and vice versa [59]. Furthermore, silicon accelerates the rate of bone mineralization and calcification as shown in controlled animal studies, in a similar manner that was demonstrated for vitamin $\mathrm{D}[11,50]$. It is well known that vitamin $\mathrm{D}$ increases the rate of bone mineralization and bone formation [60], and that its deficiency leads to less mature bone development. Vitamin $\mathrm{D}$ is known to be important in calcium metabolism, but silicondeficient cockerels' skulls in a controlled animal study 
showed lower calcification and collagen levels irrespective of the vitamin D dietary levels suggesting a vitamin D-independent mechanism of action [61]. Jugdaohsingh et al. [21] found that silicon supplementation in drinking water did not significantly altered silicon concentrations in bones and suggested that some other nutritional cofactor is required for maximal silicon uptake into bone and that this co-factor was absent in rats fed with a lowsilicon diet compared to the reference group fed by a silicon-rich diet. They suggested vitamin $K$ as such co-factor, which is important in bone mineralisation through carboxylation of osteocalcin, and whose deficiency might influence incorporation of minerals such as silicon in the bones.

\section{Osteoporosis}

Osteoporosis is among leading causes of morbidity and mortality worldwide [62]. It is defined as a progressive skeletal disorder, characterised by low bone mass (osteopenia) and micro-architectural deterioration [63]. Interestingly, the administration of silicon in a controlled clinical study induced a significant increase in femoral bone mineral density in osteoporotic women [31]. Direct relationship between silicon content and bone formation has been shown by Moukarzel et al. [64]. They found a correlation between decreased silicon concentrations in total parenterally fed infants with a decreased bone mineral content. This was the first observation of a possible dietary deficiency of silicon in humans. A randomized controlled animal study on aged ovariectomized rats revealed that long-term preventive treatment with ch-OSA prevented partial femoral bone loss and had a positive effect on the bone turnover [65]. Dietary silicon is associated with postmenopausal bone turnover and bone mineral density at the women's age when the risk of osteoporosis increases. Moreover, in a cohort study on 3198 middle-aged woman (50-62 years) it was shown that silicon interacts with the oestrogen status on bone mineral density, suggesting that oestrogen status is important for the silicon metabolism in bone health [66].

\section{Skin and hair}

Typical sign of ageing skin is fall off of silicon and hyaluronic acid levels in connective tissues. This results in loss of moisture and elasticity in the skin. Appearance of hair and nails can also be affected by lower silicon levels, since they are basically composed of keratin proteins. As previously discussed, ortho-silicic acid may stimulate collagen production and connective tissue function and repair. For example, Barel et al. [67] conducted experiments on females, aged between 40-65 years, with clear clinical signs of photo-ageing of facial skin. Their randomized doubleblinded placebo-controlled study illustrates positive effects of ch-OSA taken as an oral supplement on skin micro relief and skin anisotropy in woman with photo-aged skin. Skin roughness and the difference in longitudinal and lateral shear propagation time decreased in the ch-OSA group, suggesting improvement in isotropy of the skin. In addition, ch-OSA intake positively affected the brittleness of hair and nails. Oral supplementation with ch-OSA had positive effects on hair morphology and tensile strengths, as shown in a randomized placebo-controlled double blind study by Wickett et al. [68].

\section{Alzheimer disease}

Aluminium (as $\mathrm{Al}^{3+}$ ion) is a well-known neurotoxin. Aluminium salts may accelerate oxidative damage of biomolecules. Importantly, it has been detected in neurons bearing neurofibrillary tangles in Alzheimer's and Parkinson's disease with dementia as shown in controlled studies $[69,70]$. Amorphous aluminosilicates have been found at the core of senile plaques in Alzheimer's disease [69,71], and have consequently been implicated as one of the possible causal factors that contribute to Alzheimer's disease. Since aluminosilicates are water insoluble compounds, the transport path to the brain is still not well understood. By reducing the bioavailability of aluminium, it may be possible to limit its neurotoxicity. Consumption of moderately high amounts of beer in humans and ortho-silicic acid in animals has shown to reduce aluminium uptake from the digestive tract and slow down the accumulation of this metal in the brain tissue [36,72]. Silicic acid has also been found to induce down-regulation of endogenous antioxidant enzymes associated with aluminium administration and to normalize tumour necrosis factor alpha (TNF $\alpha$ ) mRNA expression [35]. Although the effect of silicic acid on aluminium absorption and excretion from human body produced conflicting results so far as shown in an open-label clinical study [7], in a controlled clinical study it was shown that silicic acid substantially reduces aluminium bioavailability to humans [73]. In fact, it was already found that silicon reduces the aluminium toxicity and absorption in some plants and animals that belong to different biological systems [74-76]. This is possible as silicon competes with aluminium in biological systems such as fresh water, as suggested by Birchall and Chappell study perfomed on the geochemical ground [77], and later confirmed by Taylor et al. in randomized double blind study [78]. They found that soft water contains less silicic acid and more aluminium, while hard waters contain more silicic acid and less aluminium.

Removal of aluminium from the body and its reduced absorption by simultaneous administration of silicic acid was tested and proven by Exley et al. in controlled clinical study [59]. They showed reduced urinary excretion 
of aluminium along with unaltered urinary excretion of trace elements such as iron in persons to whom silicic acid-rich mineral water was administered. Moreover, they documented that regular drinking of a silicon-rich mineral water during a period of 3 months significantly reduced the body burden of aluminium. Similar results were obtained by Davenward et al. [79] who showed that silicon-rich mineral waters can be used as a non-invasive method to reduce the body burden of aluminium in both Alzheimer's patients and control group by facilitating the removal of aluminium via the urine without any concomitant effect. They also showed clinically relevant improvements of cognitive performances in at least 3 out of 15 individuals with Alzheimer disease. This implies a possible use of ortho-silicic acid as long-term non-invasive therapy for reduction of aluminium in Alzheimer's disease patients. The mechanism through which aluminium bioavailability reduction occurs involves interaction between aluminium species and ortho-silicic acid where highly insoluble hydroxyaluminosilicates (HAS) forms are produced $[77,80]$. This process makes aluminium unavailable for absorption.

\section{Immunostimulatory effects}

Quartz as a form of crystalline silicon dioxide has been connected with severe negative biological effects. However, in controlled studies on mouse and rats it was shown that sub-chronic and short-term exposure to this compound can actually have beneficial effects on respiratory defence mechanisms by stimulating immune system through the increase of neutrophils, T lymphocytes and NK cells. It also activates phagocytes and consequently additional ROS production [81-83] which can help the pulmonary clearance of infectious agents. In rats, crystalline silica caused proliferation and activation of $\mathrm{CD}^{+} \mathrm{T}$ cells and, to a lesser amount, of $\mathrm{CD}^{+} \mathrm{T}$ cells.

Recently, an "anionic alkali mineral complex" Barodon ${ }^{\circledR}$ has shown immunostimulatory effects in horses [84], pigs [85] and other animals. Barodon ${ }^{\circledR}$ is a mixture of sodium silicate $\left(\mathrm{M}_{2} \mathrm{SiO}_{3}, \mathrm{M}=\mathrm{Na}, \mathrm{K}\right)$ and certain metal salts in an alkaline solution $(\mathrm{pH}=13.5)$, where sodiumsilicate (sodium water glass) represents $60 \%$ of the total content. In a placebo-controlled experiment in pigs, the immunostimulatory effect of Barodon ${ }^{\circledR}$ was assessed by measurement of proliferation and activation of porcine immune cells, especially $\mathrm{CD}^{+} \mathrm{CD}^{+}$double-positive (dpp) $\mathrm{T}$ lymphocytes in peripheral blood and in the secondary lymphoid organ [85]. As this type of T lymphocyte cells are characterized by a specific memory cell marker CD29, they may play a role during activation of secondary immune responses as shown in a crosssectional and longitudinal study on pigs [86]. Moreover, Barodon ${ }^{\circledR}$ acted mainly on the lymphoid organs, implying a role in antigenic stimulation of immune tissues
[85]. Barodon $^{\circledR}$ induced increased levels of MHCII lymphocytes and non-T/non-B (N) cells as well along with increased stimulatory mitogen activity including the activity of PHA, concanavalin A, and pokeweed mitogen $[85,87]$. In a placebo-controlled experiment on pigs, it was shown that this mineral complex exerts an adjuvant effect with hog cholera and Actinobacillus pleuropneumoniae vaccines by increasing the antibody titres and immune cell proportions [88]. Moreover, Barodon ${ }^{\circledR}$ showed nonspecific immunostimulating effects in racing horses and higher phagocytic activity against Staphylococcus equi subsp. equi and Staphylococcus aureus as well in a controlled study [84]. Administration of Barodon ${ }^{\circledR}$ in horse herds reduced many clinical complications, including stress-induced respiratory disease, suggesting activation of immune cell populations similarly to the treatment with inactivated Propionibacterium acnes $[89,90]$. The exact mechanism of Barodon ${ }^{\circledR}$ immunostimulatory effect is not known, although it has been suggested that sodium silicate, the main mineral ingredient, might be responsible for the observed immune-enhancing properties. Indeed, sodium silicate is known to decompose quantitatively into bioavailable ortho-silicic acid $\left(\mathrm{H}_{4} \mathrm{SiO}_{4}\right)$ in the acidic gastric juice $(\mathrm{HCl})$, and as such being absorbed in the body. In this manner, presumably all observed pharmacological effects of Barodon ${ }^{\circledR}$ are actually originated from the ortho-silicic acid.

Pure sodium metasilicate $\left(\mathrm{Na}_{2} \mathrm{SiO}_{3}\right)$ also bears immunostimulatory effects and acts as a potent mitochondria activator [91]. Dietary silicon in the form of sodium metasilicate activates formation of ammonia by elevating mitochondrial oxygen utilisation as shown in a controlled animal experiment [91]. These findings further corroborate the hypothesis that sodium silicate might be responsible for immunostimulatory effects of Barodon ${ }^{\circledR}$. Once again, the pharmacologically active species was ortho-silicic acid released upon the action of stomach hydrochlorid acid on sodium metasilicate.

\section{Zeolites as a source of ortho-silicic acid}

Zeolites are a class of aluminosilicates of general formula $\left(\mathrm{Mn}^{+}\right)_{\mathrm{x} / \mathrm{n}}\left[\left(\mathrm{AlO}_{2}\right)_{\mathrm{x}}\left(\mathrm{SiO}_{2}\right)_{\mathrm{y}}\right] \cdot \mathrm{mH}_{2} \mathrm{O}$, wherein $\mathrm{M}$ represents a positively charged metal ion such as sodium $\left(\mathrm{Na}^{+}\right)$, potassium $\left(\mathrm{K}^{+}\right)$, magnesium $\left(\mathrm{Mg}^{2+}\right)$, or calcium $\left(\mathrm{Ca}^{2+}\right)$. Zeolites are crystalline aluminosilicates with open 3D framework structures built of $\mathrm{SiO}_{4}$ and $\mathrm{AlO}_{4}$ tetrahedra linked to each other by sharing all the oxygen atoms to form regular intra-crystalline cavities and channels of molecular dimensions [92]. The positively charged metal ions (e.g. $\mathrm{Na}^{+}, \mathrm{K}^{+}, \mathrm{Ca}^{2+}, \mathrm{Mg}^{2+}$ ) are positioned in these cavities of aluminosilicate skeleton which are termed as micro- (2-20 ̊), meso- (20-50 ̊), and macro-(50-100 $\AA)$-pores. These ions are readily exchangeable in contact with aqueous solution of other positively charged 
ions (e.g. heavy metal ions like $\mathrm{Hg}^{2+}$ ). This structural characteristic of zeolites is the base of their ion (cation)exchange property [93].

At present, 191 unique zeolite frameworks have been identified [94], while over 40 naturally occurring zeolite frameworks have been described. Zeolites have been widely employed in chemical and food industries, agriculture, and environmental technologies as adsorbents, absorbents, adsorbent filter-aids, ion-exchangers, catalysts, active cosmetic and pharmaceutical ingredients, soil improvers, etc. [95-103]. Besides, zeolites exhibit a number of interesting biological activities [5,104,105] (Figure 4). For example, nontoxic natural zeolite clinoptilolite affects tumour cells proliferation in vitro and might act as an adjuvant in cancer therapy [105]. Katic et al. [106] confirmed that clinoptilolite influences cell viability, cell division, and cellular stress response that results in antiproliferative effect and apoptosis induction in vitro. Obtained results demonstrated that clinoptilolite biological effect on tumour cells growth inhibition might be a consequence of adsorptive and ion-exchange characteristics that cause adsorption of some serum components by clinoptilolite [106]. Similarly, clinoptilolite showed antiviral effects in vitro and a potential in antiviral therapy either for local skin application against herpesvirus infections or oral treatment of adenovirus or enterovirus infections [107]. The antiviral mechanism is probably non-specific and is based on adsorption of viral particles on external cavities at the clinoptilolite surface rather than a consequence of ion-exchange properties.
Each zeolite particle acts like a large inorganic molecule and acts as a molecular sieve with a potential in molecular medicine in molecular medicine. Their pores are indeed, rather small (less than $2 \mathrm{~nm}$ to $50 \mathrm{~nm}$ ) [108], and these structural similarities between the cages of zeolites and binding sites of enzymes resulted in development of zeolite structures that mimic enzyme functions [108], e.g. haemoglobin, cytochrome P450 or iron-sulphur proteins [109].

Important data on biological zeolites fate (Figure 5) and effects in vivo have been widely reported so far in the scientific literature. For example, it was shown that zeolites bear detoxifying and decontaminant properties when added to animal diets, reducing levels of heavy metals (e.g. lead, mercury, and cadmium) and various organic pollutants, i.e. radionuclides (Figure 6) and antibiotics [108]. Furthermore, zeolites have been successfully utilized for haemodialysis, for cartridges in haemoperfusions, for wound healing, and surgical incisions [108]. For instance, QuikClot and Zeomic formulations are already being marketed for haemorrhage control [110] and dental treatment [5], respectively.

Several toxicological studies proved that certain natural zeolite, e.g. clinoptiolite are non-toxic and completely safe for use in human and veterinary medicine [105]. In vitro and in vivo controlled animal studies have shown that clinoptilolite is an inert substance that may cause, in some instances, only moderate but not progressive fibrosis or mesothelioma [111]. This effect might be attributed to side-substances present in natural zeolites, e.g. silica or clay aluminosilicates [112]. It

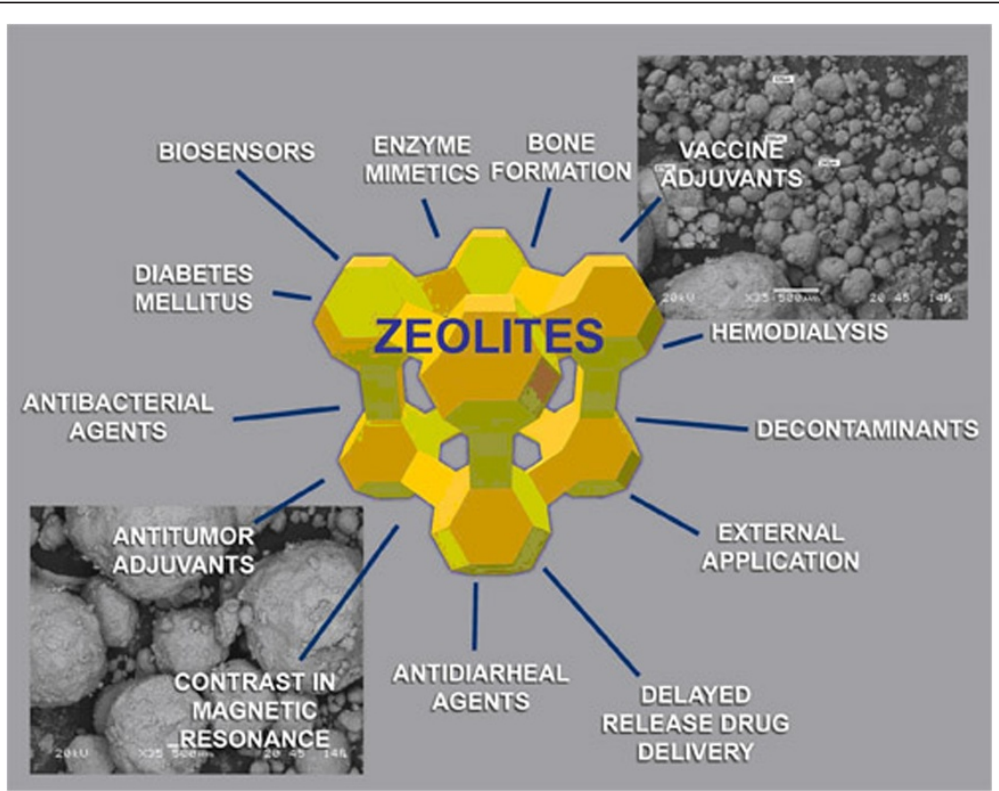

Figure 4 Biomedical application of zeolites (adopted from: K Pavelic, M Colic, B Subotic. In: Studies in Surface Science and Catalysis, Vol. 135. Amsterdam: Elsevier, 2001, p 170). 


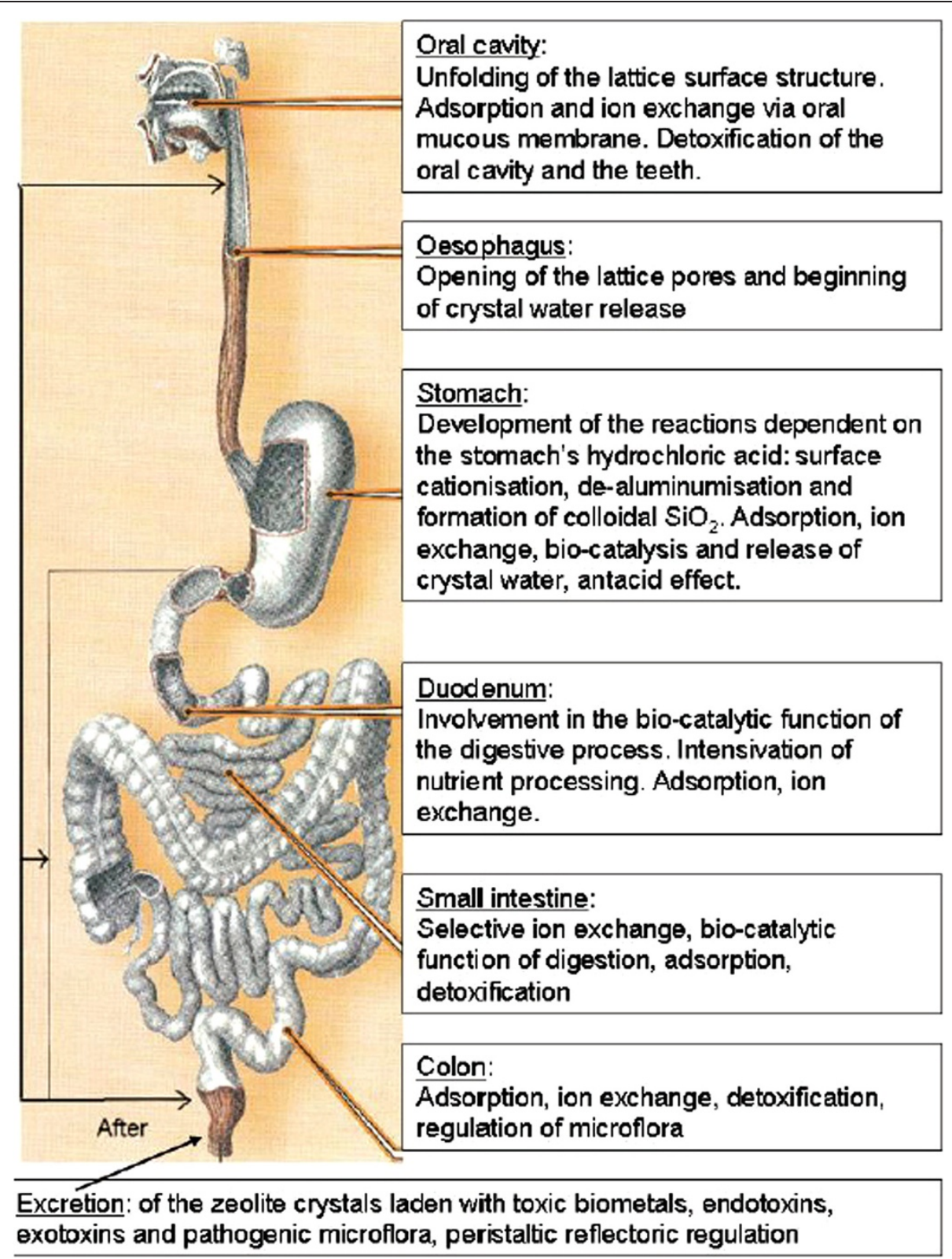

Figure 5 Structural and biochemical changes of zeolites in the digestive system (by courtesy from Application of natural zeolites in medicine and cosmetology - ZEOMEDCOS. SWB, Baku-London, 2010).

should be also stated that some zeolites might be extremely dangerous for human health and exert negative biological effects. For example, erionite, a fibrous type of natural zeolite, causes a high incidence of mesotheliomas and fibrosis in humans and experimental animals [113].

Animal studies have also shown the possibility of zeolite A (sodium aluminosilicate) as a viable source of silicon $[4,6,114]$. The latter is one of known zeolites that breaks down into bioavailable ortho-silicic acid $\left(\mathrm{H}_{4} \mathrm{SiO}_{4}\right)$ in the digestive system. This property arises from the structure of zeolite A which is characterized by the same number of aluminium and silicon atoms in zeolite $\mathrm{A}$
[115]. Zeolite $\mathrm{A}$ is hydrolysed at low $\mathrm{pH}$ (stomach hydrochloric acid) into ortho-silicic acid $\left(\mathrm{H}_{4} \mathrm{SiO}_{4}\right)$ and aluminium ions $\left(\mathrm{Al}^{3+}\right)$. These are combined back to the amorphous aluminosilicate. Such process readily provides additional source of bioavailable silicon to the organism $[114,116]$. Indeed, randomized placebo-controlled studies on dogs [114] proved that silicon is absorbed upon oral administration of zeolite A. Comparable results have been obtained in a randomized placebo-controlled research on horses as well [6]. Addition of zeolite A to the diet of young racing quarter horses have resulted in decreased skeletal injury rates and better training performance [117]. 


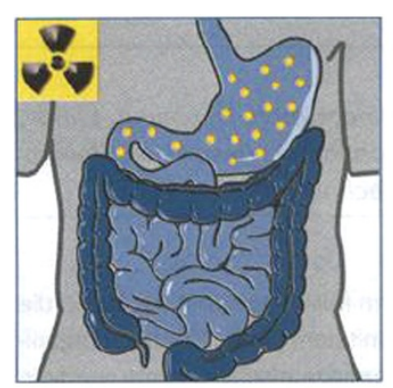

Six minutes after uptake, radiation can be detected in the organ sectors stomach and duodendum.

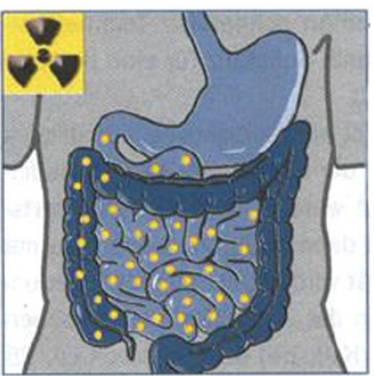

Two hundred and forty minutes afte uptake, the technetium-99m coupled MAC has completely the stomach and has partially reached the colon.

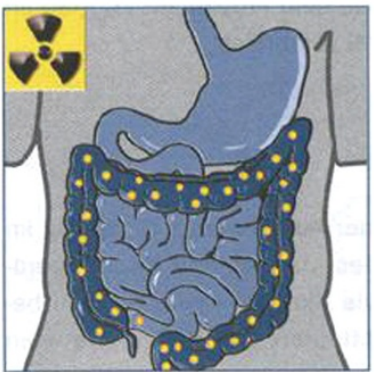

Twenty-four hours after the MAC uptake, almost all of the radiation can be detected in the colon and rectum, immediately before excretion.
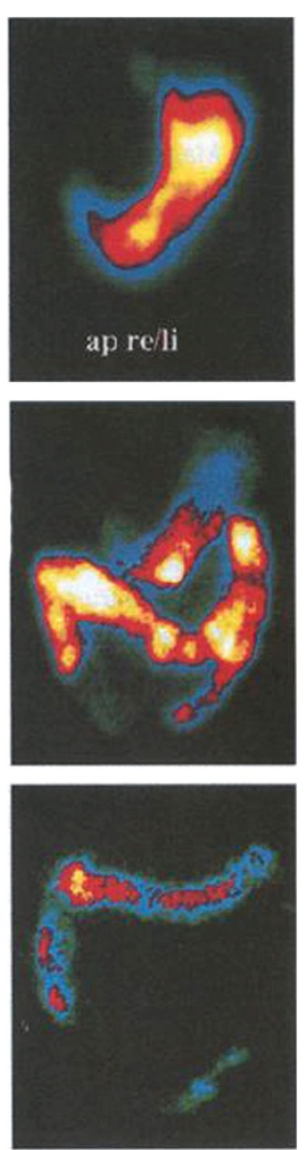

Figure 6 The fate of isotope labelled activated clinoptilolite-zeolite in the gastro-intestinal tract (by courtesy from Application of natural zeolites in medicine and cosmetology - ZEOMEDCOS. SWB, Baku-London, 2010).

However, increased bone formation was found in randomized controlled studies on broodmare horses [118], but not in yearling horses [119]. Food supplementation with zeolite A in calves showed no changes in bone architecture or mechanical properties [120]. However, in a controlled study Turner et al. [120] showed increased aluminium content in the bone and cartilage of zeolite A-fed calves which is an important safety issue for the zeolite A therapeutic usage.

\section{Conclusion}

In conclusion, we believe that ortho-silicic acid $\left(\mathrm{H}_{4} \mathrm{SiO}_{4}\right)$ might be a prominent therapeutic agent in humans. Some potential therapeutic and biological effects on bone formation and bone density, Alzheimer disease, immunodeficiency, skin, hair, and nails condition, as well as on tumour growth, have already been documented and are critically discussed in the presented paper. Acid forms of ortho-silicic acid include: choline-chloridestabilized ortho-silicic acid (ch-OSA) as a specific pharmaceutical formulation of $\mathrm{H}_{4} \mathrm{SiO}_{4}$, simple water soluble silicate salts such as sodium silicate (E550;
$\mathrm{Na}_{2} \mathrm{SiO}_{3}$ ) or potassium silicate $\left(\mathrm{E} 560 ; \mathrm{K}_{2} \mathrm{SiO}_{3}\right.$ ), and certain water-insoluble forms that, upon contact with stomach juice $(\mathrm{HCl})$, release small, but biologically significant amounts of ortho-silicic acid. The latter involves: colloidal silicic acid (hydrated silica gel), amorphous silicon dioxide (E551), certain types of zeolites such as zeolite A (sodium aluminosilicate, E554; potassium aluminosilicate, E555; calcium aluminosilicate, E556), and the natural zeolite clinoptilolite. However, for some of the above-proposed therapeutic perspectives of both orthosilicic acid and ortho-silicic acid -releasing derivatives, additional insights into biological mechanisms of action and larger studies on both animals and humans are required.

\section{Competing interest}

The authors declare no conflict of interest.

\section{Authors' contributions}

LMJ has prepared the body of the manuscript text and figures as well as performed a general literature search in particular those related to animal studies. IC has prepared the literature and manuscript parts related to orthosilic acid and zeolites chemistry as well as interpretation of biological effects in relation to chemical properties. SKP has prepared the literature and 
parts of the manuscript related to biological effects of orthosilic acid and zeolites and performed the text revision. KP provided the idea for the manuscript, medical interpretation of cited studies and performed the final text revision. All authors read and approved the final manuscript.

\section{Acknowledgements}

This work was supported by the Croatian Ministry of Science, Education and Sports (grants number 335-0982464-2393 and 335-0000000-3532).

\section{Author details}

${ }^{1}$ Department of Biotechnology, University of Rijeka, Radmile Matejčić 2, Rijeka HR-51000, Croatia. ${ }^{2}$ PharmaS Ltd, Industrijska cesta 5, Potok, Popovača HR-44317, Croatia.

Received: 3 October 2012 Accepted: 30 December 2012

Published: 8 January 2013

\section{References}

1. Greenwood NN, Earnshaw A: Chemistry of the elements. 2nd edition. Oxford: Butterworth-Heinemann; 1997.

2. Martin KR: The chemistry of silica and its potential health benefits. J Nutr Health Aging 2007, 11(2):94-97.

3. Treguer P, Nelson DM, Van Bennekom AJ, DeMaster DJ, Leynaert A, Queguiner B: The silica balance in the world ocean: A reestimate. Science 1995, 268(5209):375-379.

4. Frey KS, Pottery GD: Plasma silicon and radiographic bone density in weaning quarter horses fed sodium zeolite A. Equine Vet Science 1991, 12:292-296

5. Pavelic K, Hadzija M: Medical applications of zeolites. In Handbook of zeolite science and technology. 1st edition. Edited by Auerbach SM, Carrado KA, Dutta PK. New York: Marcel Dekker; 2003:1143-1174.

6. O'Connor Cl, Nielsen BD, Woodward AD, Spooner HS, Ventura BA, Turner KK: Mineral balance in horses fed two supplemental silicon sources. $J$ Anim Physiol Anim Nutr (Berl) 2008, 92(2):173-181.

7. Reffitt DM, Jugdaohsingh NR, Thompson RPH, Powel JJ: Silicic acid: its gastrointestinal uptake and urinary excretion in man and effects on aluminium excretion. J Inorg Biochem 1999, 76(2):141-147.

8. Jugdaohsingh R, Anderson SHC, Tucker KL, Elliot H, Kiel DP, Thompson RPH, Powell JJ: Dietary silicon intake and absorption. Am J Clin Nutr 2002, 75(5):887-893.

9. Smith BL: Analysis of hair element levels by age, sex, race, and hair color. In Trace elements in man and animals, TEMA 8. Edited by Anke M, Meissner D, Mills CF. New York: Kluwer; 1993:1091-1093.

10. Austin JH: Silicon levels in human tissues. Nobel Symp 1997, :255-268

11. Carlisle EM: Silicon: an essential element for the chick. Science 1972 178:619-621.

12. Fregert S: Studies on silicon in tissues with special reference to skin. J Invest Dermatol 1958, 31(2):95-96.

13. European Food Safety Authority: Opinion of the scientific panel on dietetic products, nutrition and allergies on a request from the commission related to the tolerable upper intake level of silicon. The EFSA Journal 2004, 60:1-11.

14. Scientific Committee for Food: Nutrient and energy intakes for the European Community. Reports of the Scientific Committee for Food (Thirty-first series). Luxembourg: European Commission; 1993.

15. Institute of Medicine, Food and Nutrition Board: Dietary reference intakes for vitamin A, vitamin K, arsenic, boron, chromium, copper, iodine, iron, manganese, molybdenum, nickel, silicon, vanadium, and zinc. Washington: National Academy Press; 2000.

16. Varo P, Koivistoinen P: Mineral element composition of Finnish foods. Acta Agric Scand 1980, 22:165-171.

17. Bowen HJM, Peggs A: Determination of the silicon content of food. J SCl Food Agric 1984, 35:1225-1229.

18. Bellia JP, Birchall JD, Roberts NB: Beer: a dietary source of silicon. Lance 1994, 343(8891):235.

19. Pennington JAT: Silicon in food and diets. Food Addit Contam 1991 8(1):97-118.

20. MCNaughton SA, Bolton-Smith C, Mishra GD, Jugdaohsingh R, Powell JJ: Dietary silicon intake in post-menopausal women. Br J Nut 2005, 94:813-817
21. Jugdaohsingh R, Calomme MR, Robinson K, Nielsen F, Anderson SHC, D'Haese P, Geusens P, Loveridge N, Thompson RPH, Powell JJ: Increased longitudinal growth in rats on a silicon-depleted diet. Bone 2008, 43(3):596-606.

22. Van Dyck K, Van Cauwenbergh $\mathrm{R}$, Robberecht $\mathrm{H}$, Deelstra H: Bioavailability of silicon from food and food supplements. Fresenius J Anal Chem 1999, 363:541-544.

23. Barnett PR, Skougstad MW, Miller KJ: Chemical characterization of a public water supply. J Am Water Works Assoc 1969, 61:61-68.

24. Sripanyakorn S, Jugdaohsingh R, Elliott H, Walker C, Mehta P, Shoukru S: The silicon content of beer and its bioavailability in healthy volunteers. Br J Nutr 2004, 91(3):403-409.

25. Jugdaohsingh R, Reffitt DM, Oldham C, Day JP, Fifield LK, Thompson RPH: Oligomeric but not monomeric silica prevents aluminum absorption in humans. Am J Clin Nutr 2000, 71(4):944-949.

26. Popplewell JF, King SJ, Day JP, Ackrill P, Fifield LK, Cresswell RG, et al: Kinetics of uptake and elimination of silicic acid by a human subject: a novel application of ${ }^{32} \mathrm{Si}$ and accelerator mass spectrometry. J Inorg Biochem 1998, 69(3):177-180.

27. Calomme R, Cos P, D'Haese PC, Vingerhoets $R$, Lamberts LV, De Broe ME, et al: Absorption of silicon in healthy subjects. In Metal ions in biology and medicine. Volume 5. Edited by Collery P, Brätter P, Negretti De Brätter V, Khassanova L, Etienne JC. Paris: John Libbey Eurotext; 1998:228-232.

28. Berlyne GM, Adler AJ, Ferran N, Bennett S, Holt J: Silicon metabolism. I. Some aspects of renal silicon handling in normal man. Nephron 1986, 43(1):5-9.

29. European Food Safety Authority: Scientific opinion of the panel on food additives and nutrient sources added to food. The EFSA Journal $2009,948: 1-23$.

30. Budavari S: Merck index: An encyclopaedia of chemicals, drugs, and biologicals. 11th edition. Rahway: Merck \& Co; 1989:342-343.

31. Eisinger J, Clairet D: Effects of silicon, fluoride, etidronate and magnesium on bone mineral density: a retrospective study. Magnes Res 1993, 6(3):247-249.

32. Lassus A: Colloidal silicic acid for oral and topical treatment of aged skin fragile hair and brittle nails in females. J Int Med Res 1993, 21(4):209-215.

33. Schwarz K: Silicon, fibre, and atherosclerosis. Lancet 1977, 1(8009):454-457.

34. Schwarz K, Ricci BA, Punsar S, Karvonen MJ: Inverse relation of silicon in drinking water and atherosclerosis in Finland. Lancet 1977. 1(8010):538-539.

35. Candy JM, Edwardson JA, Klinowski J, Oakley AE, Perry EK, Perry RH: Colocalisation of aluminum and silicon in senile plaques: implications for the neurochemical pathology of Alzheimer's disease. In Senile dementia of the Alzheimer type. Edited by Traber J, Gispen WH. Heidelberg: Springer; 1985:183-197.

36. Gonzalez-Munoz MJ, Meseguer I, Sanchez-Reus MI, Schultz A: Beer consumption reduces cerebral oxidation caused by aluminum toxicity by normalizing gene expression of tumor necrotic factor alpha and several antioxidant enzymes. Food Chem Toxicol 2008, 46(3):1111-1118

37. Maehira F, Ishimine N, Miyagi I, Eguchi Y, Shimada K. Anti-diabetic effects including diabetic nephropathy of anti-osteoporotic trace minerals on diabetic mice. Nutrition 2010, 27(4):488-495.

38. Dobbie JW, Smith MJB: The silicon content of body fluids. Scott Med J 1982 27:17-19.

39. Carlisle EM: Silicon. In Biochemistry of the essential ultratrace elements. Edited by Frieden E. New York: Plenum Press; 1984:257-291.

40. Bissé $E$, Epting $T$, Beil $A$, Lindinger $G$, Lang $H$, Wieland $H$ : Reference values for serum silicon in adults. Anal Biochem 2005, 337(1):130-135.

41. Van Dyck K, Robberecht H, Van Cauwenbergh R, Van Vlaslaer V, Deelstra H: Indication of silicon essentiality in humans. Serum concentrations in Belgian children and adults, including pregnant women. Biol Trace Elem Res 2000, 77(1):25-32.

42. Adler AJ, Berlyne GM: Silicon metabolism II. Renal handling in chronic renal failure patients. Nephron 1986, 44:36-39.

43. D' Haese PC, Shaheen FA, Huraid SO: Increased silicon levels in dialysis patients due to high silicon content in the drinking water, inadequate water treatment procedures, and concentrate contamination: a multicentre study. Nephrol Dial Transplant 1995, 10:1838-1844.

44. Maehira F, Motomura K, Ishimine N, Miyagi I, Eguchi Y, Teruya S: Soluble silica and coral sand suppress high blood pressure and improve the related aortic gene expressions in spontaneously hypertensive rats. Nutr Res 2011, 31(2):147-156. 
45. Carlisle EM: The nutrition essential of silicon. Nutr Rev 1982, 40:193-198

46. Carlisle EM: Silicon: a possible factor in bone calcification. Science 1970 167:279-280.

47. Carlisle EM: In vivo requirement for silicon in articular cartilage and connective tissue formation in the chick. J Nutr 1976, 106:478-484

48. Carlisle EM: Biochemical and morphological changes associated with long bone abnormalities in silicon deficiency. J Nutr 1980, 110:1046-1055.

49. Carlisle EM: Silicon localization and calcification in developing bone. Fed Proc 1969, 28:374.

50. Carlisle EM: A relationship between silicon and calcium in bone formation. Fed Proc 1970, 29:565

51. Schwarz K, Miline DB: Growth promoting effects of silicon in rats. Nature 1972, 239(537):333-334.

52. Seabron CD, Nielsen FH: Dietary silicon affects acid and alkaline phosphatase and ${ }^{45}$ calcium uptake in bone of rats. J Trace Elem Exp Med 1994, 7:1-11.

53. Seabron CD, Nielsen FH: Dietary silicon and arginine affect mineral element composition of rat femur and vertebra. Biol Trace Elem Res 2002, 89:239-250.

54. Reffitt DM, Ogston N, Jugdaohsingh R, Cheung HFJ, Evans BAJ, Thompson $\mathrm{RPH}$, et al: Orthosilicic acid stimulates collagen type 1 synthesis and osteoblastic differentiation in human osteoblast-like cells in vitro. Bone 2003, 32(2):127-135.

55. Keeting PE, Oursler MJ, Wiegand KE, Bonde SK, Spelsberg TC, Riggs BL: Zeolite $A$ increases proliferation, differentiation, and transforming growth factor production in normal adult human osteoblast like cells in vitro. J Bone Miner Res 1992, 7(11):1281-1289.

56. Schutze, Oursler MJ, Nolan J, Riggs BL, Spelzberg TC: Zeolite A inhibits osteoclast mediated bone resorption in vitro. J Cell Biochem 1995, 58(1):39-46

57. Carlisle EM: A silicon-molybdenum interrelationship in vivo. Fed Proc 1979, 38:553.

58. Carlisle EM, Curran MJ: Effect of dietary silicon and aluminum on silicon and aluminum levels in rat brain. Alzheimer Dis Assoc Dis 1986, 1(2):83-89.

59. Exley C, Korchazhkina O, Job D, Strekopytov S, Polwart A, Crome P: Noninvasive therapy to reduce the body burden of aluminium in Alzheimer's disease. J Alzheimers Dis 2006, 10(1):17-24.

60. Muller SA, Posner AS, Firschein HE: Effect of vitamin D deficiency on the crystal chemistry of bone mineral. Proc Soc Exp Biol Med 1966 121(3):844-846.

61. Carlisle EM: Silicon: a requirement in bone formation independent of vitamin D. Calcif Tissue Int 1981, 33:27-34.

62. Spector TD, Calomme MR, Anderson SH, Clement G, Bevan L, Demeester N, et al: Choline-stabilized orthosilicic acid supplementation as an adjunct to calcium/vitamin D3 stimulates markers of bone formation in osteopenic females: a randomized, placebo-controlled trial. BMC Musculoskelet Disord 2008, 9:85-95.

63. Marcus R: Clinical review 76: the nature of osteoporosis. J Clin Endocrinol Metab 1996, 81(1):1-5.

64. Moukarzel AA, Song M, Buchman AL, Ament ME: Silicon deficiency may be involved in bone disease of parenteral nutrition. J Am Coll Nutr 1992, 11:584.

65. Calomme M, Geusens P, Demeester N, Behets GJ, D'Haese P, Sindambiwe $J B$, et al: Partial prevention of long-term femoral bone loss in aged ovariectomized rats supplemented with choline-stabilized orthosilicic acid. Calcif Tissue Int 2006, 78(4):227-232.

66. Macdonald HM, Hardcastle AC, Jugdaohsingh R, Fraser WD, Reid DM, Powell J): Dietary silicon interacts with oestrogen to influence bone health: Evidence from the Aberdeen Prospective Osteoporosis Screening Study. Bone 2012, 50(3):681-687.

67. Barel A, Calomme M, Timchenko A, De Paepe K, Demeester N, Rogiers V, Clarys P, Vanden Berghe D: Effects of oral intake of choline-stabilized orthosilicic acid on skin, nails, and hair in women with photodamaged skin. Arch Dermatol Res 2005, 297:147-153.

68. Wickett RR, Kossmann E, Barel A, Demeester N, Clarys P, Vanden Berghe D, et al: Effect of oral intake of choline-stabilized orthosilicic acid on hair tensile strength and morphology in woman with fine hair. Arch Dermatol Res 2007, 299(10):499-505.

69. Perl DP, Brody AR: Alzheimer's disease: X-ray spectrometric evidence of aluminium accumulation in neurofibrillary tangle-bearing neurons. Science 1980, 208(4441):297-309.

70. Perl DP: Relationship of aluminium to Alzheimer's disease. Environ Health Perspect 1985, 63:149-153.
71. Candy JM, Oakley AE, Klinowski J, Carpenter TA, Perry EK, Blessed G, et al: Aluminosilicates and senile plaque formation in Alzheimer's disease. Lancet 1986, 1(8477):354-357

72. González-Muñoz MJ, Pena A, Meseguer I: Role of beer as a possible protective factor in preventing Alzheimer's disease. Food Chem Toxicol 2008, 46(1):49-56.

73. Edwardson JA, Moore PB, Ferrier IN, Lilley JS, Newton GWA, Barker J, et al: Effect of silicon on gastrointestinal absorption of aluminium. Lancet 1993, 342(8865):211-212

74. Birchall JD, Exley C, Chappell JS, Phillips MJ: Acute toxicity of aluminium to fish eliminated in silicon-rich acids waters. Nature 1989, 338:146-148.

75. Hammond KE, Evans DE, Hodson MJ: Aluminium/silicon interactions in barley (Hordeum vulgare L.) seedlings. Plant Soil 1995, 173(1):89-95.

76. Exley C: A biogeochemical cycle for aluminium. J Inorg Biochem 2003, 97(1):1-7.

77. Birchall JD, Chappell JS: Aluminium, water chemistry, and Alzheimer's disease. Lancet 1989, 1(8644):953.

78. Taylor GA, Newens AJ, Edwardson JA, Kay DW, Forster DP: Alzheimer's disease and the relationship between silicon and aluminium in water supplies in northern England. J Epidemiol Community Health 1995, 49(3):323-324

79. Davenward S, Bentham P, Wright J, Crome P, Job D, Polwart A, Exley C: Silicon-rich mineral water as a non-invasive test of the 'aluminum hypothesis' in Alzheimer's disease. J Alzheimers Dis 2012, to be published.

80. Exley C, Schneider C, Doucet FJ: The reaction of aluminium with silicic acid in acidic solution: an important mechanism in controlling the biological availability of aluminium. Coord Chem Rev 2002, 228(2):127-135.

81. Antonini JM, Roberts JR, Yang HM, Barger MW, Ramsey D, Castranova V, et al: Effect of silica inhalation on the pulmonary clearance of a bacterial pathogen in Fischer 344 rats. Lung 2000, 178(6):341-350.

82. Antonini JM, Yang HM, Ma JY, Roberts JR, Barger MW, Butterworth $L$, et al: Subchronic silica exposure enhances respiratory defense mechanisms and the pulmonary clearance of Listeria monocytogenes in rats. Inhal Toxicol 2000, 12(11):1017-1036.

83. Kumar RK: Quantitative immunohistologic assessment of lymphocyte populations in the pulmonary inflammatory response to intratracheal silica. Am J Pathol 1989, 135(4):605-614.

84. Koo HC, Ryu S-H, Ahn HJ, Jung WK, Park YK, Kwon NH, et al: Immunostimulatory effects of the anionic alkali mineral complex BARODON on equine lymphocytes. Clin Vaccine Immunol 2006 13(11):1255-1266

85. Yoo BW, Choi SI, Kim SH, Yang SJ, Koo HC, Seo SH, et al: Immunostimulatory effects of anionic alkali mineral complex solution Barodon in porcine lymphocytes. J Vet Sci 2001, 2(1):15-24.

86. Zuckermann FA, Husmann RJ: Functional and phenotypic analysis of porcine peripheral blood CD4/CD8 double-positive T cells. Immunology 1996, 87(3):500-512.

87. Yoo BW, Choi SI, Kim SH, Yang SJ, Koo HC, Kown NH, et al: Immunostimulatory effects of anionic alkali mineral complex solution Barodon in porcine lymphocytes. J Swine Health Prod 2002, 10:265-270.

88. Park BK, Park YH, Seo KS: Lymphocyte subpopulations of peripheral blood in pigs treated with an ionized alkali mineral complex. J Vet Sci 1999, 24:67-74.

89. Moore BR, Krakowska S, Robertson JT: Evaluation of an immunostimulant in preventing shipping related respiratory disease. J Equine Vet Sci 1996, 16:78.

90. Flaminio MJ, Rush BR, Shuman W: Immunologic function in horses after non-specific immunostimulant administration. Vet Immunol Immunopathol 1998, 63(4):303-315.

91. Oner G, Cirrik S, Bakan O: Effects of silica on mitochondrial functions of the proximal tubule cells in rats. Kidney Blood Press Res 2005, 28(4):203-210.

92. Libau F: Structural chemistry of silicates. Berlin: Springer; 1985.

93. Cejka J, Heyrovsky J (Eds): Zeolites and ordered mesoporous materials: progress and prospects, Stud Surf Sci Catal, Volume 157. Amsterdam: Elsevier; 2005.

94. Baerlocher C, Meier WH, Olson DH: Atlas of zeolite framework types. 6th edition. Amsterdam: Elsevier; 2007.

95. Flaningen EM: Molecular sieve zeolite technology - the first five years. In Proceedings of the $5^{\text {th }}$ international conference of zeolites. Edited by Rees LV. London: Heyden; 1980:760-780.

96. Sersale R: Natural zeolites: processing, present and possible applications. Stud Surf Sci Catal 1985, 24:503-512.

97. Naber JE, De Jong KP, Stork WHJ, Kuipers HPCE: Post industrial application of zeolite catalysis. Stud Surf Sci Catal 1994, 84:2197-2220. 
98. Pavelić K: Medical News 1998, 26:21-22.

99. Colella C: Natural zeolites in environmentally friendly processes and applications. Stud Surf Sci Catal 1999, 125:641-655

100. Garaces JM: Observations on zeolite applications. In Proceedings of the $12^{\text {th }}$ international conference of zeolites. Edited by Treacz MMJ, Marcus BK, Misher ME, Higgins JB. Warrendale: Materials Research Society; 1999:551-566.

101. Mumpton FA: La roca magica: uses of natural zeolites in agriculture and industry. Proc Natl Acad Sci 1999, 96(7):3463-3470.

102. Yang RT: Adsorbents, fundamentals and applications. New York: John Wiley \& Sons Inc; 2003.

103. Loidelsbacher T: Process for manufacturing fertilizers or soil amendments from mineral and organic components. Munich: European Patent Publication (EP 0444392 B1); 1993.

104. Rodriguez-Fuentes G, Barrios MA, Iraizoz A, Perdomo I, Cedre B: Enterex: Anti-diarrheic drug based on purified natural clinoptilolite. Zeolites 1997 19:441-448

105. Pavelić K, Hadzija M, Bedrica L, Pavelić J, Dikić I, Katić M: Natural zeolite clinoptilolite: new adjuvant in anticancer therapy. J Mol Med 2001 78(12):708-720.

106. Katic M, Bosnjak B, Gal-Troselj K, Dikic I, Pavelic K: A clinoptilolite effects on cell media and the consequent effects on tumor cells in vitro. Front Biosci 2006, 11:1722-1732

107. Grce M, Pavelić K: Antiviral properties of clinoptilolite. Microporous and Mesoporous Materials 2005, 79:165-169.

108. Kralj M, Pavelić K: Medicine on a small scale. EMBO Rep 2003, 4(11):1008-1012.

109. Bedioui F: Zeolite-encapsulated and clay-intercalated metal porphyrin, phthalocyanine and Schiff-base complexes as models for biomimetic oxidation catalysts: an overview. Coord Chem Rev 1995, 144:39-68.

110. Rhee P, Brown C, Martin M, Salim A, Plurad D, Green D, et al: QuikClot use in trauma for hemorrhage control: case series of 103 documented uses. J Trauma 2008, 64(4):1093-1099.

111. Adamis Z, Tatrai E, Honma K, Six E, Ungvary G: In vitro and in vivo tests for determination of the pathogenicity of quartz, diatomaceous earth, modernite and clinoptilolite. Ann Occup Hyg 2000, 44(1):67-74.

112. Kogan FM, Nikitina OV: Solubility of chrysotile asbestos and basalt fibres in relation to their fibrogenic and carcinogenic action. Environ Health Perspect 1994, 102(5):205-206.

113. Baris YI, Sahin AA, Ozemi M, Kerse I, Ozen E, Kolacan B, et al: An outbreak of pleural mesothelioma and chronic fibrosing pleurisity in the village of Karani/Urgup in Anatolia. Thorax 1978, 33:181-192.

114. Cefali EA, Nolan JC, McConnell WR, Lowe Walters D: Bioavailability of silicon and aluminium from zeolite A in dogs. Int Journ Pharm 1996, 127(2):147-154.

115. Hartman RL, Fogler HS: Understanding the dissolution of zeolites. Langmuir 2007, 23(10):5477-84.

116. Thilsing-Hansen $T$, Jorgensen RJ, Enemark JM, Larsen T: The effect of zeolite $A$ supplementation in the dry period on periparturient calcium, phosphorus, and magnesium homeostasis. J Dairy Sci 2002, 85(7):1855-1862.

117. Nielsen BD, Potter GD, Morris EL, Odom TW, Senor DM, Reynolds JA Training distance to failure in young racing quarter horses fed sodium zeolite a. J Equine Vet Sci 1993, 13:562-567.

118. Lang KJ, Nielsen BD, Waite KL, Hill GM, Orth MW: Supplemental silicon increases plasma and milk silicon concentrations in horses. J Anim Sci 2001, 79(10):2627-2633.

119. Lang KJ, Nielsen BD, Waite KL, Link J, Hill GM: Increased plasma silicon concentrations and altered bone resorption in response to sodium zeolite $\mathrm{A}$ supplementation in yearling horses. J Equine Vet Sci 2001, 21:550-555.

120. Turner KK, Nielsen BD, O'Connor Cl, Robison DS, Rosenstein DS, Marks BP, et al: Sodium zeolite a supplementation and its impact on the skeleton of dairy calves. Biol Trace Elem Res 2008, 121(2):149-159.

doi:10.1186/1743-7075-10-2

Cite this article as: Jurkić et al:: Biological and therapeutic effects of ortho-silicic acid and some ortho-silicic acid-releasing compounds: New perspectives for therapy. Nutrition \& Metabolism 2013 10:2.

\section{Submit your next manuscript to BioMed Central and take full advantage of:}

- Convenient online submission

- Thorough peer review

- No space constraints or color figure charges

- Immediate publication on acceptance

- Inclusion in PubMed, CAS, Scopus and Google Scholar

- Research which is freely available for redistribution

Submit your manuscript at www.biomedcentral.com/submit
C Biomed Central 